\title{
Service quality in sport: A case study of golf resorts in the Liberec region
}

\author{
Eva Čáslavová, Markéta Pecinová*, Tomáš Ruda, Martin Šíma
}

Faculty of Physical Education and Sport, Charles University, Prague, Czech Republic

* Corresponding author: pecinova@ftvs.cuni.cz

\begin{abstract}
In the sport service environment, the level of customer satisfaction is monitored more and more thoroughly. The assumption is that a satisfied customer remains loyal for a longer period of time, buys more new products, talks favourably about the service provided, pays less attention to competing services, is less sensitive to price, and provides the company with new ideas for service improvement.

Aim. The aim of this paper is to assess the level of customer satisfaction with golf resorts in the Liberec region. The survey evaluates the satisfaction of 78 customers at four golf courses in the Liberec region.

Methods. Customer satisfaction was surveyed using a standardized questionnaire adjusted to Czech conditions and based on the SERQUAL model. This method identifies gaps between customer expectations and perceived quality of golf courses. It seeks to assess customer satisfaction with the golf course, the golf course amenities, the services offered, the golf course staff, the club staff, and the golf resort management. Results. Overall results showed that the customers were most satisfied with the services at Grabštejn Golf Course (total gap 0.02), while Malevil Golf Course and Ypsilon Golf Course had the same negative result (total gap -0.22 ) and the worst negative gap was at the Ještěd Golf Course (-1.24). The results show that there is room for managers to improve their services. In all cases the biggest gap appeared in the "Satisfaction with the course" dimension (except at Ypsilon GC), Ypsilon GC had the biggest problem in the "Satisfaction with staff" dimension (-0.72). Also the customers at the Malevil GC claim that they are dissatisfied with the golf resort management $(-0.74)$.

Conclusion. There is room for improvement at all golf courses that took part in this research. Customers are mostly dissatisfied and they evaluated the service provided as low quality in most of the dimensions. Generally the worst area is the golf course and staff. At the Ještěd $G C$, the results show that the management of the golf course is at a low level.
\end{abstract}

\section{KEYWORDS}

customer expectations; customer satisfaction; golf, service marketing; SERVQUAL

DOI

10.14712/23366052.2018.11

(C) 2018 The Authors. This is an open-access article distributed under the terms of the Creative Commons Attribution License (http://creativecommons.org/licenses/by/4.0), which permits unrestricted use, distribution, and reproduction in any medium, provided the original author and source are credited. 


\section{INTRODUCTION}

In the sports environment, golf - now an Olympic sport - has grown both in popularity and importance. Various companies do business in the golf environment now. In their endeavour to succeed and to reach and attract customers, companies seek ways to differentiate themselves and their offerings from their competitors. Their goal is to retain customers on a long-term basis. To attain an advantageous position in the market it is essential to be able to respond quickly to customers' requirements and to adjust the company's offering appropriately.

Organizations should offer services that are able to meet their customers' expectations. They should develop a service proposition based on a survey of customer needs in all relevant market segments together with monitoring competitors' performance (Payne, 1996). The process of investigating customer needs is an interactive process called Customer Relationship Management that aims at achieving the proper balance between the company's investments and meeting the customer's needs. The ideal balance is determined by maximum benefit and profit enjoyed by both parties (Chlebovský, 2005). A long-term loyal relationship with customers is essential for achieving the best possible results, and this is especially true in the golf environment as golf clubs depend entirely on their members. Often, proceeds from the membership fees are the main source of revenues, without which many golf centres could not manage. Managers try hard to create a perfect atmosphere and pleasant ambience for their customers so that they feel comfortable there, remain loyal to their golf course, and keep coming back. It is generally acknowledged in the service sector that to find a new customer is far more challenging (financially, organizationally, and otherwise) than to retain a current one. The main goal is to create a situation where the customer is proud to represent the club.

Satisfaction is a state in which the customer's needs have been met in full and the expectations of all service quality attributes have been matched or exceeded (Kotler \& Armstrong, 2004; Cronina, Brady, \& Hult, 2000; Schneider \& White, 2004). Customer satisfaction is defined as a judgement or an opinion that a product or service feature, or product or service itself, is providing (or has provided) a pleasurable level of consumption-related fulfilment (Oliver, 2010).

Determining whether or not there is a relationship between the service quality and customer satisfaction is an issue that has been discussed in literature for several years. Based on expectations from both quality and customer satisfaction, a close link exists between these concepts (Zeithaml \& Bitner, 1996; Berry \& Parasuraman, 1991; Zamazalová, 2009). A customer has many expectations in relation to service provision. He or she expects certain functions, speed of service provision, certain conduct and behaviour of the staff, etc. It is assumed that the customer expects a specific level of satisfaction for each service attribute.

Numerous studies indicate that people tend to share their positive experience with four to five other people, but that they will complain about their negative experience to as many as nine to ten people. Negative feedback spreads much faster and has an adverse impact on the company's performance. The quality of service provided is very important although it is not easy to determine what quality means. After searching through definitions by many authors (Spencer, 1994; Vodáček \& Vodáčková, 2009; 
Fisk, Grove, \& John, 2000), "requirement compliance" seems to be a fitting expression to characterize quality. A deeper meaning of the term can be found in the definition by Svozilová (2006) who defines quality as a set of product features able to meet explicit or assumed needs.

According to Šíma (2014) various methods are used in the research of service quality in sport, e.g. mystery shopping, audit quality, SERVQUAL, SERVPERF (Cronin \& Taylor, 1994; Rai, 2013), SERVIMPERF (Haller, 1998), TQM (Nenadál, 2004), SQAS (Lam, Zhang, \& Jensen, 2005), QUESC (Kim \& Kim, 1995) or Penalty Method (Brandt, 1987), ECSI (Kristensen, Martensen, \& Gronholdt, 2000), and Brady's model (Brady, Cronin, 2001). When applied to a specific sport, the methods listed above are properly adjusted and transformed. As a widely recognized and well-proven approach valued by many authors, the SERVQUAL method (Zeithaml, Parasuraman, \& Berry, 1990; Śíma \& Ruda, 2011; Foberová, 2010, Siami \& Gorji, 2012; Lukášová, 2009) based on the GAP model was applied as the main tool to investigate customer satisfaction with selected golf resorts. In total, five gaps were identified based on qualitative research. This paper deals with Gap 5 that results from the previous gaps 1 to 4 and determines the difference between what customers expect and what is actually offered by the providing company.

\section{AIM}

The aim of this paper is to evaluate the service quality and customer satisfaction among the golf resorts in the Liberec region. Making use of the results achieved, provisions for better performance will be suggested to those organizations that received the lowest scores from their customers on the quality of service provided. Moreover, this paper provides specific details of the analysis of results by means of the SERVQUAL method.

\section{METHODS}

To research golf players' satisfaction with the service offered by golf resorts, two primary data collection techniques were employed: written survey, electronic survey. Players on the golf courses were asked to fill in a written questionnaire. Other visitors of golf resorts who could not be reached at the golf course were surveyed electronically.

The written questionnaire consists of three main parts, includes 63 questions, and is based on the SERVQUAL model (Parasuraman, Zeithaml, \& Berry, 1985). This research uses the same principals, and the indicators were modified for the area of golf. There are several critics of SERVQUAL (Cronin, Brady, \& Hult, 2000). They point out that the expectation is dependent on the life experience and therefore SERVQUAL cannot measure the real quality of service rather than satisfaction. Others claim (Šíma \& Ruda, 2011; Haller, 1998) that this is not relevant in all areas and that sport is one of them. The same authors explain that only frequent visitors, who are aware of high quality services, evaluate sport services.

The first part of the questionnaire included nine questions focused on demographic and psychographic data and, at the same time, it investigates regular attendance at 
each particular golf course. Respondents were asked to indicate the option that they agree with most.

The second part consisted of 52 questions divided into six sub-groups (see Figure 1).

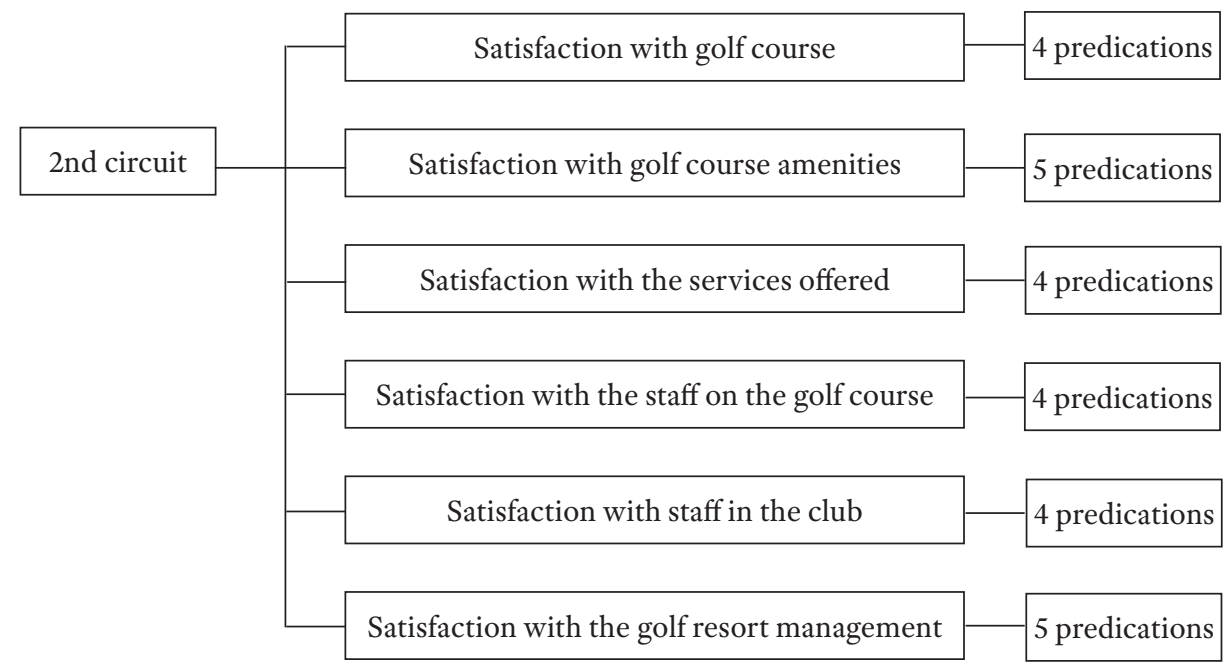

Figure 1 Conceptualisation of the SERVQUAL questionnaire modified for the area of golf

Respondents were asked to score each statement on a scale from 1 to 7 , where 1 signifies "totally disagree" and 7 signifies "totally agree." The arithmetic mean is calculated from the sum of all scores to set the averages of both the expected service quality and the service quality delivered. The difference between them determines the gap value. A positive value indicates that the surveyed customer is happy about the service since the service quality delivered is perceived as higher than the service quality generally expected. Any negative value means dissatisfaction. To determine unambiguously which type of service is perceived by customers as having poor quality, it is necessary to focus on the negative values of the gap. The established results are displayed in radial figure (see Figure 1). Figure 1 displays the satisfaction ratio of each sub-group.

The resulting evaluation is performed as the sum of all responses with help of the arithmetic mean, averaging the expected quality of services and actually provided, and the difference between them is the value of the gap. It is important to focus on the highest negative and positive gaps in order to find out which type of service the golf resort customers are most satisfied with or dissatisfied with (Table 2-6).

The questionnaire ends with two open-ended questions. Here, customers were asked to name the biggest weakness and strength of the given golf resort.

The survey was performed from August 2014 through to the end of February 2015 and it involved both men and women of various age groups, jobs, monthly incomes, and golf handicaps. With 700 questionnaires handed out, 295 correctly filled questionnaires were returned. The questionnaire return rate was $42 \%$. The original intent to reach approximately the same sample of respondents of each age group given in 
the questionnaire, however, has not been met. The main reason for this was that not all golf players approached were willing to participate in the survey and that made fulfilling the sample difficult.

The basic characteristics of the respondents are shown in Table 1.

Table 1 Characteristic of the respondents

\begin{tabular}{lcc}
\hline Gender & Number of respondents & Percentage \\
\hline Male & 189 & $64 \%$ \\
Female & 106 & $36 \%$ \\
Total & 295 & \\
\hline Age group & Number of respondents & Percentage \\
\hline Below 20 years & 24 & $8 \%$ \\
$21-30$ years & 70 & $24 \%$ \\
$31-40$ years & 54 & $18 \%$ \\
$41-50$ years & 59 & $20 \%$ \\
$51-60$ years & 46 & $16 \%$ \\
Above 60 years & 42 & $14 \%$ \\
Total & 295 & \\
\hline
\end{tabular}

\section{RESULTS}

Total research carried out on all the courses. 295 respondents from Prague and the Liberec region participated in the survey. Table 1 show the exact distribution to the individual groups surveyed. Distribution of age groups is approximately the same representation, with the exception of the age group under 20 years of research, which involved only $8 \%$ of respondents.

Four golf courses (with 78 participants) are selected for this paper, because their results are significantly different from others and seem interesting. The following is the list of golf courses representing the Liberec region: Ypsilon Golf Resort Liberec, Královský Golf Club Malevil, Ještěd Golf Club, Grabštejn Golf Club.

\section{Ještěd Golf Club}

Unfortunately, in this club, employees were reluctant to participate in this research. This reluctance of the club's staff was confirmed in the evaluation of the questionnaire, when it was often stated that the club should be more interested in the needs of its members and better communicate with them.

Ještěd Golf Club was ranked as the worst club among all venues, as was the case in the Liberec region. Table 2 shows the greatest dissatisfaction with the golf course, with staff in the club and with the golf resort management. On the contrary, most players were satisfied with golf course amenities and with staff on the golf course. 
Table 2 Extent of gaps identified for the main customer satisfaction factors at Ještěd GC - the biggest gap

\begin{tabular}{lcccccc}
\hline Satisfaction & $\begin{array}{c}\text { With } \\
\text { golf } \\
\text { course }\end{array}$ & $\begin{array}{c}\text { With golf } \\
\text { course } \\
\text { amenities }\end{array}$ & $\begin{array}{c}\text { With } \\
\text { services } \\
\text { offered }\end{array}$ & $\begin{array}{c}\text { With staff } \\
\text { on the golf } \\
\text { course }\end{array}$ & $\begin{array}{c}\text { With } \\
\text { staff in } \\
\text { the club }\end{array}$ & $\begin{array}{c}\text { With the golf } \\
\text { resort } \\
\text { management }\end{array}$ \\
\hline Gap & -1.74 & -0.56 & -1.51 & -0.62 & -1.64 & -1.5 \\
Total gap & & & & -1.24 & & \\
\hline
\end{tabular}

Table 2 shows the overall gap, as well as the gaps in each satisfaction factor. In the case of Ještěd GC, the total gap size was -1.24 , indicating high dissatisfaction with the services provided.

Other questions find satisfaction or dissatisfaction with individual factors of golf resorts. Customers were only satisfied with a large enough parking space and never had parking problems here. On the contrary, the players were most dissatisfied with the management's lack of interest in their needs. Then, they were dissatisfied with the quality of greens, maintenance of lawns throughout the golf season, lack of motivation for continuous membership in the club and the impossibility of relying on all customer service. Generally, players are most dissatisfied with the golf course and staff in the club.

\section{Grabštejn Golf Club}

Grabštejn Golf Club is located about $20 \mathrm{~km}$ from Liberec and has nine holes. The satisfaction with Grabštejn GC is shown in Table 3.

Table 3 Extent of gaps identified for the main customer satisfaction factors at Grabštejn GC - the smallest gap

\begin{tabular}{lcccccc}
\hline Satisfaction & $\begin{array}{c}\text { With } \\
\text { golf course }\end{array}$ & $\begin{array}{c}\text { With golf } \\
\text { course } \\
\text { amenities }\end{array}$ & $\begin{array}{c}\text { With } \\
\text { services } \\
\text { offered }\end{array}$ & $\begin{array}{c}\text { With staff } \\
\text { on the golf } \\
\text { course }\end{array}$ & $\begin{array}{c}\text { With } \\
\text { staff in } \\
\text { the club }\end{array}$ & $\begin{array}{c}\text { With the golf } \\
\text { resort } \\
\text { management }\end{array}$ \\
\hline Gap & -0.29 & -0.02 & 0.38 & -0.27 & 0.15 & 0.15 \\
Total gap & & & & 0.02 & & \\
\hline
\end{tabular}

Players at the Grabštejn GC are more satisfied than dissatisfied. Table 4 shows that the first dimension (satisfaction with golf course) and fourth dimension (satisfaction with staff on the golf course) are the places where the management should focus and improve their service.

Table 3 also shows the total value of the gaps, which is 0.02 , which is a positive number and it means that players were satisfied with the services offered. However, it still shows that players feel very happy here.

The results showed that players are most dissatisfied with the capacity of the parking, as mentioned in the chapter on the services provided on the individual courses. There are very few places in the car park, and for larger events it is necessary to use the grassy area about $200 \mathrm{~m}$ from the clubhouse. Other factors that customers were not very satisfied with include poor understanding of trainers' interpretation of training lessons. On the contrary, the greatest satisfaction prevails with the distribution of all the important points of the course, such as the first and tenth hole, the training area, etc. As this is a smaller nine-hole course, this result is not a surprise. Furthermore, the 
players were happy with the number of tournaments that Grabštejn GC had prepared during the season.

\section{Královský Golf Club Malevil}

Communication and cooperation with this club was very positive. Interest of management and reception in the satisfaction of their players was noticeable. KGC Malevil ranked fourth in the Liberec county. Table 4 shows the greatest dissatisfaction with the golf resort management while, on the contrary, most players were satisfied with golf course amenities.

Table 4 Extent of gaps identified for the main customer satisfaction factors at Královský Golf Club Malevil - the same gap as Ypsilon Golf Liberec

\begin{tabular}{lcccccc}
\hline Satisfaction & $\begin{array}{c}\text { With } \\
\text { golf course }\end{array}$ & $\begin{array}{c}\text { With } \\
\text { golf course } \\
\text { amenities }\end{array}$ & $\begin{array}{c}\text { With } \\
\text { services } \\
\text { offered }\end{array}$ & $\begin{array}{c}\text { With } \\
\text { staff on the } \\
\text { golf course }\end{array}$ & $\begin{array}{c}\text { With } \\
\text { staff in } \\
\text { the club }\end{array}$ & $\begin{array}{c}\text { With the golf } \\
\text { resort } \\
\text { management }\end{array}$ \\
\hline Gap & -0.33 & 0.13 & -0.35 & -0.03 & 0.04 & -0.74 \\
Total gap & & & \multicolumn{2}{c}{-0.22} & & \\
\hline
\end{tabular}

Table 4 shows the satisfaction rate of each factor and the total value of -0.22 . This value indicates relative satisfaction with KGC Malevil services.

Focusing on individual questions, customers are most dissatisfied with not being invited by management representatives to club tournaments and lack of awareness of upcoming events. In addition, there are insufficiently prepared greens with the correct cutting height, grass quality for the entire season, and disruption of the game by the greenskeeper in area maintenance. On the other hand, players were satisfied with the location of all the important points of the course, the professional and elegant appearance of staff in the club, and with the professional approach of the coaches.

\section{Ypsilon Golf Liberec}

Most of the players were happy with the golf course and with the golf course amenities that are definitely the best in the region, with the highest budget. Players were satisfied with staff on the golf course. Respondents complained about the reluctance of some employees and their behaviour in some situations on the golf course. One of the reasons for dissatisfaction may be the situation with club coaches.

At present only one professional coach operates in the club, which is insufficient and so players prefer clubs with more choices. The players were also dissatisfied with the fact that management was not interested in their needs. The most dissatisfaction was with the inadequate motivation of players to continue membership. This is one thing the managers should focus on and they focused on it in the 2015 season. Too high entry fees caused this problem, however, since the 2015 season, the fee has fallen to one fifth and the club's situation is getting better. The greatest satisfaction was with the number of tournaments that players can take part in, in total there were 99 tournaments. 
Table 5 Extent of gaps identified for the main customer satisfaction factors at Ypsilon Golf Resort Liberec - the same gap as Královský Golf Club Malevil

\begin{tabular}{lcccccc}
\hline Satisfaction & $\begin{array}{c}\text { With } \\
\text { golf } \\
\text { course }\end{array}$ & $\begin{array}{c}\text { With } \\
\text { golf course } \\
\text { amenities }\end{array}$ & $\begin{array}{c}\text { With } \\
\text { services } \\
\text { offered }\end{array}$ & $\begin{array}{c}\text { With staff } \\
\text { on the golf } \\
\text { course }\end{array}$ & $\begin{array}{c}\text { With staff } \\
\text { in the } \\
\text { club }\end{array}$ & $\begin{array}{c}\text { With the golf } \\
\text { resort } \\
\text { management }\end{array}$ \\
\hline Gap & -0.09 & -0.05 & -0.24 & -0.72 & -0.19 & -0.34 \\
Total gap & & & & -0.22 & & \\
\hline
\end{tabular}

Table 5 indicates that the players at Ypsilon GC were relatively satisfied. The greatest satisfaction was with golf course amenities; the lowest satisfaction was with staff on the golf course.

Table 6 shows final satisfaction with golf clubs in the region under study. In the Liberec region the players are most satisfied with the services at Grabštejn GC and at least in Ještěd GC.

Table 6 Satisfaction in the Liberec region

\begin{tabular}{lc}
\hline Course & Total Gap \\
\hline Grabštejn & 0.02 \\
Malevil & -0.22 \\
Ypsilon & -0.22 \\
Ještěd & -1.24 \\
\hline
\end{tabular}

\section{DISCUSSION}

In the course of contacting the selected resorts with the purpose of carrying out the survey, certain signs of annoyance were expressed by the owners of the golf clubs. Some of them refused to take part in the survey and were, therefore, replaced by other clubs. The fact that the resort management is unwilling to cooperate in a customer satisfaction survey was later confirmed by the analysis of questionnaires. Ještěd Golf Club showed the strongest unwillingness. While distributing the questionnaires, it became apparent that this unwillingness is not confined only to the surveyor, but was also directed at customers. It was observed at the golf courses that the customers' requirements are not in the forefront of the management's interest; the customers often feel ignored and neglected. In this case, it would help if there a further qualitative survey among the customers to find out the exact experience was done. The negative attitude is more than obvious in the analysed results of Ještěd GC.

This research is a unique source of information about customer satisfaction with services in mentioned golf clubs. The practical contribution of this research can be considered, in particular, as a proposal for a methodical procedure for assessing the quality of services in the golf resorts. The SERVQUAL method respects the aspect of comprehensiveness involved in the defined constructs and is applicable to various sport establishments - both for-profit and not-for-profit organizations. Its frequent application to assess the quality of service is a proof of this (Murray \& Howat, 2002; 
Saleh \& Ryan, 2006; Kouthouris \& Alexandris, 2007). The use of this method provides the management of golf establishments with an opportunity to enhance customer satisfaction, strengthen their loyalty and, in the form of recommendation, attract new customers to golf services. To achieve a more comprehensive picture, it can be combined with other methods. In this case, the method could be combined with interviews with golf players and the golf resort management.

Cronin, Brady, \& Hult (2000) claim in their study that SERVQUAL cannot evaluate more then the satisfaction of the customers and that this method cannot evaluate the quality of service. This claim can be disputed because on one hand the data shows the connection between the size of the gap and the evaluation of the service on the scale, and on the other hand the researcher could see that if there are visible problems with the service, people evaluated the problem in the questionnaire.

Looking at the SERVQUAL method and its application in the sport sector, it should be noted that it only measures functional quality (how services are delivered to a customer), but not technical quality (what is delivered to a customer) (Šíma, 2014). It is, however, questionable to assume how high the expectations are as this is the basis on which the customer determines the real perception of service quality. Expectations may be quite high, and although the perception of what is delivered does not match them, the customer may still be satisfied. In such a case, the resulting negative values indicate an exaggerated level of expectations rather than dissatisfaction.

When surveyed using the SERVQUAL method, respondents are asked to express which rating on a Likert scale best represents their expectations and actual perception of service. A seven-point scale was used for this survey where the surveyor primarily sought the gap between the selected responses. A positive value of the gap indicates satisfaction with service provided by the golf resort, while a negative value indicates that the surveyed customer experiences dissatisfaction. The surveyor works with the difference of values without further investigating whether the resulting gap $(-1)$ is the difference between values 7 and 6 , or values 3 and 2, which may significantly affect the opinion.

The theoretical benefits of this paper may be considered theoretical procedure, which with exceptions, have not yet been made available in the domestic literature. Theoretical approaches to the measurement of quality of services have been defined on the basis of a search of foreign professional literature. To understand the complexity of the solved field were studied various methods for evaluation of service quality in sport. For this paper was chosen SERVQUAL method, which seemed adequate to achieve the aim of this paper. This paper provides specific details of the analysis of results by means of the SERVQUAL method.

Ruda, Augustova, \& Šíma (2012) claim that even though SERVQUAL has many limitations, this method is good for evaluation of service quality in sport. This study can be confirmed because the collected data gave reasonable and quick feedback from the customers and highlights the areas where the service provided should be improved.

\section{CONCLUSION}

The survey provided interesting information that is useful mainly for golf resort staff. The available data make it possible to see which attributes of service quality are essential for the perception of a golf course and which are of minor importance for customers. 
Ještěd GC received the biggest negative rating from the players (customers). Unsatisfactory customer care provided by the staff and poor tee quality are considered to be the most serious drawbacks. Customers complain about muddy tees, which can be caused by too much felt lining under the surface. Should this be the case, it is recommended to increase the intensity of turf punching for better core aeration and to re-seed the tees. The location of the golf course and the profile of certain holes, on the other hand, were perceived as positive features. As regards the unsatisfactory customer care on the part of the staff, it is recommended to organize more golf tournaments and other social events focused on the members. Such events would give the members opportunities to meet not only other members, but also staff members, and share their impressions and previous experience with the resort. It is informal meetings that often give rise to interesting insights and ideas for improving the existing offer. In the best case, the bonds between the members and staff members can strengthen and relations improved on a longer-term basis.

The results showed that the customers are most satisfied with the services at Grabštejn Golf Course (total gap 0.02) Malevil Golf Course and Ypsilon Golf Course had the same negative total gap -0.22 . The worst negative total gap $(-1.24)$ was at the Ještěd Golf Course. The results also show that there is a place for managers to improve their services. In all cases the biggest gap appeared in the "Satisfaction with the course" dimension. This was different at Ypsilon GC; Ypsilon GC had the biggest problem with the "Satisfaction with staff" dimension $(-0.72)$. Also the customers at the Malevil GC claim that they are dissatisfied with the golf resort management. This is represented by the negative gap -0.74 .

The previous findings were used to suggest improvements not only for Ještěd GC, but also for the remaining 3 golf resorts (see Šíma, 2015). Based on the data collected, these resorts do not face serious problems and their main challenge for the future is to maintain at least the same, or even higher, quality of service than they presently provide.

This survey showed that the Liberec region is a specific area with a nice view, mountains, forests, and all together beautiful nature. Considering that Liberec is really close to Germany, it can be assumed that players here have experience with golf courses in Germany and therefore they have higher expectations of the service quality. The pitted terrain also makes it difficult for the developers to make 18-hole golf courses because of the needed space. On the other hand customers are generally satisfied with the familiar atmosphere because of the limited size and number of people visiting such golf courses.

\section{ACKNOWLEDGEMENTS}

The project was supported by scientific programme Progres Q19. 


\section{REFERENCES}

Berry, L. L., \& Parasuraman, A. (1991). Marketing Services: Competing through quality. New York: The Free Press.

Brady, M. K., \& Cronin, J. J. JR. (2001). Some new thoughts on conceptualizing perceived quality: A hierarchical approach. Journal of marketing, 65(3), 34-49.

Čáslavová, E., \& Čmakalová, H. (2015). Competition and customer loyalty of fitness centres in the Prague region compared to the Prague-West area. Studiva sportiva, 1, 144-151.

Chlebovský, V. (2005). CRM: Řizení vztahů se zákazníky. Brno: Computer Press.

Cronin, J. J., Brady, M. K., \& Hult, G. T. M. (2000). Assessing the effects of quality, value, and customer satisfaction on consumer behavioral intentions in service environment. Journal of Retailing, 76(2), 193-218.

Fisk, R. P., Grove, S. J., \& John, J. (2000). Interactive Services Marketing. Boston, New York: Houghton Mifflin.

Foberová, L. (2010). Trend ve službách: management kvality. Retrieved 11/25, 2013, from http://knihovna.nkp.cz/knihovnaplus102/forber.htm.

Haller, S. (1998). Beurteilung von Dienstleistungsqualität: Dynamische Betrachtung des Qualitätsurteils im Weiterbildungsbereich. Wiesbaden: Deutscher Universitäts-Verlag.

Kotler, P., \& Armstrong, G. (2004). Marketing. Prague: Grada Publishing.

Kotler, P., \& Keller, K. L. (2007). Marketing Management. 12th ed. Prague: Grada Publishing.

Kouthouris, Ch., \& Alexandris, K. (2005). Can service quality predict customer satisfaction and behavioral intentions in the sport tourism industry? An application of the SERVQUAL model in an outdoors setting. Journal of Sport Tourism, 10(2), 101-111.

Kristensen, K., Martensen, A., \& Gronholdt, L. (2000). Customer satisfaction measurement at Post Denmark: results of application of the European Customer Satisfaction Index methodology. Total Quality Management, 11(7), 1007-1015.

Lukášová, R., et al. (2009). Měrení spokojenosti občanů s veřejnými službami jako součást ř́zení kvality v organizacích veřejného sektoru. Brno: Tribun EU.

Murray, D., \& Howat, G. (2002). The relationships among service quality, value, satisfaction, and future intentions of customers at an Australian sports and leisure centre. Sport Management Review, 5(1), 25-43.

Nenadál, J. (2004). Měřenív systémech managementu jakosti. Prague: Management Press.

Oliver, R. L. (2010). Satisfaction: A behavioral perspective on the consumer. Routledge: M. E. Sharpe.

Parasuraman, A., Zeithaml, V. A., \& Berry, L. L. (1985). A conceptual model of service quality and its implications for future research. Journal of Marketing, 49(4), 41-50.

Payne, A. (1996). Marketing služeb. Prague: Grada Publishing.

Rai, A. K. (2013). Customer Relationship Management: Concepts and Cases (2nd ed.). New Delhi: PHI Learning.

Ruda, T., Augustová, M., \& Šíma, J. (2012). Aplikace metody SERVQUAL pro hodnocení kvality služeb ve sportu. Česká kinantropologie, 16(4), 47-54.

Schneider, B., \& White, S. S. (2004). Service Quality: research perspectives. California: Sage Publications.

Siami, S., \& Gorji, M. (2012). The measurement of service quality by using servqual and quality gap model. Indian Journal of Science and Technology, 5(1), 1956-1960.

Šíma, J. (2014). Kvalita tělovýchovných a sportovních služeb v pražských fitness centrech z pohledu zákazníka. Doctoral thesis. Charles University, Prague. 
Šíma, J., \& Ruda, T. (2011). Customer Perception of Service Quality in Sport. Acta Universitatis Carolinae. Kinanthropologica, 47(2), 68-77.

Šíma, M. (2015). Spokojenost zákazníků s nabídkou služeb golfových hřišt'v Praze a Libereckém kraji. Doctoral thesis. Charles University, Prague.

Spencer, B. A. (1994). Models of organization and total quality management: A comparison and critical evaluation. Academy of Management Review, 19(3), 446-471.

Svozilová, A. (2006). Projektový management. Prague: Grada Publishing.

Vaštíková, M. (2011). Marketing služeb efektivně a modern. Prague: Grada Publishing.

Vodáček, L., \& Vodáčková, O. (2009). Moderní management v teorii a praxis. Prague: Management Press.

Zamazalová, M. (2009). Marketing obchodní firmy. Prague: Grada Publishing.

Zeithaml, V. A., \& Bitner, M. J. (1996). Services Marketing. New York: McGrawHill.

Zeithaml, V. A., Parasuraman, A., \& Berry, L. L. (1990). Delivering Quality Service: Balancing Customer Perceptions and Expectations. New York: Free Press. 